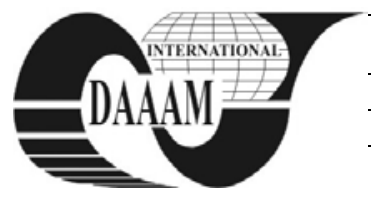

\title{
VALUES OF THE EUROPEAN CITIZENSHIP UNDER THE LEGAL MEMBERSHIP OR QUALITY
}

\author{
MIRONOV DURET, G[abriela] N[icoleta]; POCORA, M[onica]; GOGA, G[ina] L[ivioara]; NECSULESCU, \\ E[caterina]; DURET, N[icu] \& POCORA, M[ihail] - S[ilviu]
}

\begin{abstract}
This paper aims at analyzing the difference between the groups that have European citizenship by those who have been entrusted with it - stateless persons, foreigners and other subjects related to citizenship, the rights which may be involved in such a state, the extension of the European citizens' rights and ensuring the real integration of these groups. As a consequence, the study approaches both aspects of free movement of persons within the European space, and also the controversial views on the principle of non-discrimination, as a fundamental constitutional right.

The main argument of the paper is that despite certain developments towards granting rights based on 'personhood' and not 'nationhood'.
\end{abstract}

Keywords: European citizenship, discrimination, rights, freedom of movement

\section{INTRODUCTION}

Considering that citizenship is considered a paradigm of political sciences, it can be said that this scientific study shows theoretical valences, the methods used in its descriptive development being predominantly observation and reasoning. Thus, we are allowed to interpret the democratic processes in terms of membership, political participation, identity, rights and responsibilities, this paper presenting the interdisciplinary nature of scientific investigation. In other words, citizenship exploits various concepts - key of political theory, in an explanatory model of democratic society. Starting from the onset of the phrase 'European citizenship', there have been frequent debates within the legal argument, but it is not a limited topic, considering that the political needs of each member state of the European Union are constantly changing, especially due to aspiring to rally to the European identity and unity.

By institutionalizing this legal status, in accordance with the Community institutions, they are enhancing the citizens' opportunities to participate in the Community integration process in a more intense way (Olsen, 2011).

\section{THE EUROPEAN CITIZENSHIP - ACTUALLY CONCEPT AND IDEA}

When referring to the age of citizenship concept, we can generally say that it has exactly the same age as the first sedentary communities. The concept of citizenship refers to those who are (or are not) members of the same community. Although the citizenship is a concept with a clear political character, there come up, however, two problems regarding its exercising, which show that the approach of the political dimension is not sufficient for a proper understanding. Thus, who and under what conditions can benefit from citizenship is not just a problem that belongs to the legal field and to the formal nature of the rights involved, it is also an issue for citizens' non-political skills derived from the social resources that they have access to.
An issue raised by the exercise of citizenship, will be that of the consequences of progress in gaining civil rights, especially for the social relations between citizens (and noncitizens) and for the economic and social institutions where they carry out their activity. Here, we can illustrate especially those groups disadvantaged in society who will fight for citizens' rights in order to improve their living conditions. Thus, this question naturally arises: can the extension of the participation in the life of a society based on citizenship status reduce the inequalities between social classes or structures or may it affect the relations between people of different sexes or races?

Answering this question, we agree that joining the European citizenship would significantly reduce the inequalities that might exist at some point in the relations between communities (Vrabie, 2007). The cultural rights appear as a new generation of rights after the civil, political and socioeconomic rights. But, nevertheless, we believe that the cultural dimension of citizenship is different from the other rights, as it embraces a much broader framework, being connected by common values, by a common identity, historical heritage, common language and the desire of all actors to achieve a joint project to include ethnic minorities and immigrants from the EU Member States.

The notion of citizenship has different meanings, depending on how it is perceived by different people (Bîrsan, 2003). It is a very usual term that captures attention, although there is not a unitary concept yet, no matter how controversially it was debated in the work of many authors.

Strictly speaking, the existential condition of citizenship is the ability to have rights (subjective rights according to the theory of positive law) and be able to implement them.

\section{THE EUROPEAN CITIZENSHIP - A STATUS OF RIGHTS}

As a status of rights, the citizenship helps to observe the composite nature of the European Union, which it itself is a law community, a socio-economic system, becoming more and more a political entity. The rights, used for the first time in Maastricht Treaty and subsequently completed in the European Constitution, exist in other regulations. In the end, it is about three rights, three of them political (the rest of the economic, social rights being already guaranteed for the citizens of each member state in one way or another, especially by the fact that all member states are parties of international conventions and declarations in this field). We underline the right of free movement and residence throughout the Union for all European citizens.

The status of European citizen is subject to possession or acquisition of nationality of a member state. The national law shall determine the conditions under which a person can acquire nationality. Certain difficulties may arise if a person possesses more than one nationality and one of which is a nonmember state of the Union. If we analyze the international 
jurisprudence on this matter, we find that the nationality opposability of a citizen towards some countries is subject to the existence "of an actual relationship with the state."

\section{THE EUROPEAN CITIZENSHIP - THE STATEMENT OF EU}

The various EU countries have important differences in the way of granting and withdrawing nationality (some recognize the ius soli and ius sanguinis systems). The states that limit the granting of citizenship reluctantly agree to open borders, labor market, or to grant the same civil and political rights to nationals of other countries. following the adoption of the TUE (EU Treaties), the member states were required to establish uniform electoral procedures and to form some trans-European political parties, which have the role of forming " a European awareness and expression of political will by the citizens of the Union." Furthermore, by TUE they officially recognized the role of institutional actors in the process of European integration. But soon, the voices of numerous Euro-skepticals did not fail to appear and contest "the democratic deficit" in EU institutions, but also that by TUE, the national states did not renounce the sovereignty and a part of their powers in favor of a common authority. In principle, the member states defined the concept of European citizenship, however, it should be reminded that the democratic deficit is not purely institutional (Radaelli, 2003), due to the lack of involvement of European political parties, media and public opinion in the institutional matters. The concept of European citizenship was introduced by TEC, as a result of the efforts of the member states to move from an economic union to a political union. This is part of the whole European integration process of forming a new European identity, which is defined by the fundamental rights, of persons' freedom of movement, of civil and political rights. Following the affiliation of TUE, every member state has to define the conditions for the acquisition or loss of citizenship. Furthermore, by the establishment of EU citizenship, the intention was to enhance the rights and interests of nationals of member states.

Moreover, it should be noted that the evolution of the concept of EU citizenship was made on two directions, one vertical, approaching the issue of immigration, asylum and citizenship in European Union Treaties, and a horizontal one, which addresses the human rights in the international relations system of the United Nations and in the European system. We believe that, once integrated into the European Union, all Member States must provide equal legal treatment to their citizens wherever they move in the inter-community space, if there is not a reasonable argument for a difference of treatment. Consequently, any Romanian citizen must enjoy the status of European citizen anywhere in the community space, like a French or Belgian citizen and should not be regarded only as a Romanian citizen, he should not be associated exclusively as belonging to the Romanian state, thus eliminating any form of discrimination that might occur. As a result, we should impose equality as a means of protection against unequal treatment or discrimination based on knowing that some groups of Romanian citizens, for example, are treated less favorably or excluded as they have other characteristics than the dominant group. It should be noted that the EU legislation on freedom of movement and formation of the single market was compatible only with those who are nationals of Member States. The European Union policy on citizenship led to an uneven distribution of social rights between citizens and non-citizens, preventing the economic operations and the provision of basic social rights of nationality, and finally led to the differentiation between "the active status of nationals" and " the passive obedience of "the residents of Member States. In other words, the citizens of a Member State could become "active subjects" in another Member State.

\section{THE EUROPEAN CITIZENSHIP - A POLITICAL INSTITUTION}

European citizenship is the expression of all political processes or of intergovernmental negotiations, interpretations, social mobilization and community impulses. It is precisely at this level where we can find "the dynamics of citizenship" (Muraru, I., Tănăsescu, E., Iancu, Deaconu, St., Horia M., 2005), its novelty and its most controversial aspects. The specialized literature stresses the fact that one major obstacle in forming and establishing a European citizenship is just its constantly evolving character, which confers a measure of instability and unpredictability. It is therefore difficult to tell which is the exact nature of this strange concept of citizenship, which does not appear to be subject to any German national tradition of jus sanguinis, or to the French one of the civic citizenship, but which combines both of them, competing the state sovereignty to edict on its citizens and claiming from it as it is defined by the rules of each Member State to determine citizenship. Considering the definition of citizenship, that it concerns both the active participation in public life and the ability to influence the European public politics, a natural question arises whether a Romanian citizen can actually influence the public European politics or it is just a matter of doctrine (Barsan, 2005).

\section{CONCLUSIONS}

Citizenship should create a real European society which individuals should relate to, but simply imposing this as a necessity by the European institutions towards citizens, is not sustainable on long term. The economic, political and legal rights can create European citizens de jure but they make only a material element that needs to be doubled by a deep sense of belonging to the European Union to overcome rivalries and national cultures. From the above mentioned aspects, we have noticed that the Union citizenship does not represent a certain status, defined by a set of rights and obligations. It is about an identity expressed by all its political members. From a legal perspective, we can state that the concept of the Union citizenship is merely a terminological innovation through which a new political entity should be defined.

Although, lacking the possibility to define who can be a "European citizen", through the insertion of EU citizenship supranational legislation has undermined one of the hallmarks of sovereignty, i.e. member governments' authority to privilege their own citizens (Maas, 2009).

\section{REFERENCES}

Barsan, C. (2005). European Citizenship, p. 26. Bucharest: Ed. Politeia-SNSPA

Bîrsan, C. (2003). E.U.and European Convention of Human Rights. Bucharest: RRDC

Maas, W. (2009). Contingent Citizenship and reversible rights in the European Union. Columbia Jurnal of European Law, 265-280

Muraru, I., Tănăsescu, E., Iancu, Deaconu, St., Horia M. (2005). European citizenship, p. 54. Bucharest: Ed. All Beck

Olsen, E. D. (2011). European Citizenship - With a nation state, federal or cosmopolitan twist? Arena working paper , 2

Radaelli, C. (2003). The Europeanization of Public Policy, p.27-56. . Oxford University Press

Vrabie, M. (2007). Citizenship and human rights, p.25. Bucharest: Ed. Tritonic 